\title{
MENTAL WELL-BEING, POSITIVE HEALTH OUTCOMES AND RISK BEHAVIORS AMONG IMMIGRANT ADOLESCENTS IN KAZAKHSTAN
}

\author{
Shynar Z ABDRAKHMANOVA ${ }^{1}$, https://orcid.org/0000-0003-3504-0427, \\ Assel A ADAYEVA ${ }^{1}$, https://orcid.org/0000-0001-9013-5248, \\ Tatyana I SLAZHNEVA², https://orcid.org/0000-0003-3632-486X, \\ Botagoz S TULTAEVA ${ }^{1}$, https://orcid.org/0000-0002-8424-9641 \\ ${ }^{1}$ National Center of Public Health MoH RK, Nur-Sultan c., Republic of Kazakhstan, \\ 2Kazakhstan's Medical University "Kazakhstan School of Public Health", Almaty c., Republic of Kazakhstan
}

Each country can become a country of origin, transit or destination of refugees and migrants. Often, the decision to immigrate is made by adult family members, without taking into account the views of children. As a result, immigration can act as a traumatic factor for them, as it involves a break from the usual socio-cultural environment (yard, city, school, etc.) and established social circle (classmates, acquaintances, friends). In this regard, the health of migrant children is part of public health.

Objective. This study examined the impact of migration status on positive health outcomes and well-being and risk behaviours in adolescents in the Republic of Kazakhstan.

Material and methods. Analysis is based on Health behavior in School-Aged Children survey (HBSC) first ever conducted in Kazakhstan in 2017-208 academic year. The target population - 11, 13 and 15 year old adolescents: $(n=3992)(49.5 \%$ girls), among them 191 first generation migrant adolescents $(4.8 \%), 329$ second- generation migrants $(8.2 \%)$ and 3472 native-born, non-immigrant adolescents $(87.0 \%)$.

Results and discussion. Immigrant and non-immigrant adolescents did not differ in prevalence of fair/poor self rated health, high life satisfaction, multiple health complaints. More first generation immigrants than non-immigrants and second generation immigrant peers experienced mental health problems. The frequencies of cigarette smoking, e-cigarette and alcohol use, as well as bullying and cyber bullying were significantly higher among first generation immigrants than among natives and second-generation immigrant adolescents.

Conclusions. In Kazakhstani context, migration has a negative impact for adolescent mental well-being and risk behaviors, especially for first generation immigrants.

Keywords: immigration, adolescents, positive health, mental well-being, mental health, risk behaviors.

For reference: Abdrakhmanova ShZ, Adayeva AA, Slazhneva TI, Tultaeva BS. Mental well-being, positive health outcomes and risk behaviors among immigrant adolescents in Kazakhstan. Meditsina (Almaty) = Medicine (Almaty). 2019;7-8(205-206):2-9 (In Russ.). DOI: 10.31082/1728-452X-2019-205206-7-8-2-9

\section{т¥ жы Р Ы}

ҚАЗАҚСТАНДАҒЫ ИММИГРАНТ-ЖАСӨСПІРІМДЕРДІҢ АРАСЫНДАҒЫ ПСИХИКА ТҰРАҚТЫЛЫҒЫ, ҚАЛЫПТЫ ДЕНСАУЛЫҚ ПЕН ҚАУІПТІ МІНЕЗ-ҚҰЛЫҚТАР ТУРАЛЫ

Шынар 3. ӘБДІРАХМАНОВА ${ }^{1}$, https://orcid.org/0000-0003-3504-0427,

Әсел А. АДАЕВА', https://orcid.org/0000-0001-9013-5248,

Татьяна И. СЛАЖНЁВА ${ }^{2}$, https://orcid.org/0000-0003-3632-486X,

Бөтагоз С. ТУЛТАЕВА', https://orcid.org/0000-0002-8424-9641

Contacts: Botagoz S Tultaeva, Chief Specialist of the Research Department, National Center for Public Health, Nur-Sultan, 8 Migilik el street, House of Ministries, entrance $18 \mathrm{~V}$.

E-mail:bo_nita@mail.ru

Контакты: Тултаева Ботагоз Сериковна, главный специалист отдела научных исследований, «Национальный центр общественного здравоохранения г. Нур-Султан, ул. Мәңгілік ел, дом 8, Дом Министерств, подъезд 18 В.

E-mail:bo_nita@mail.ru

Поступила 04.07.2019
${ }^{1}$ Қоғамдық денсаулық сақтау ұлттық орталығының ғылым және кәсіби даму департаменті, Нұр-Сұлтан қ., Қазақстан Республикасы,

${ }^{2}$ Қазақстан медицина университеті «Қоғамдық денсаулық сақтау жоғары мектебі», Алматы қ., Қазақстан Республикасы

Әрбір ел босқындар мен көшіп-қонушылардың шыққан, транзиті немесе тағайындалған елі бола алады. Көбінесе көшіп келу туралы шешімді балалардың пікірін ескермей, отбасының ересек мүшелері қабылдайды. Нәтижесінде, иммиграция олар үшін жарақаттаушы фрактор ретінде әрекет ете алады, өйткені әдеттегі әлеуметтік-мәдени ортадан (аула, қала, мектеп және т.б.) және қалыптасқан қарым-қатынас шеңберінен (сыныптастар, таныстар, достар) үзуді болжайды. Осыған байланысты мигрант Балалардың денсаулығы қоғамдық денсаулықтың бір бөлігі болып табылады.

Бұл зерттеу жұмыстарында көші-қон статусының Қазақстандағы жасөспірімдердің оң денсаулық, әл-ауқаттары мен ҚАУІПТІ тәртіп көрсеткіштеріне әсері қарастырылған.

Материал және әдістері. Талдау «2017-2018 оқу жылында Қазақстанда алғаш рет өткізілген « Мектеп жасындағы балалардың денсаулығы » сауалнамасына негізделген. Мақсатты топ - 11, 13 және 15 жас аралығындағы жасөспірімдер болып табылады: (n = 3 992) (49,5\% қыздар), соның ішінде бірінші буын (4,8\%) 191 жасөспірім мигрант, екінші буында 329 мигрант (8,2\%) және елдің 3472 тұрғыны, иммигрант емес жасөспірімдер (87,0\%). 
Нәтижелері және талқылауы. Иммигрант жасөспірімдер менжергілікті тұрғын-жасөспірімдердің өмірлік қанағаттану дәрежесі, денсаулықтарына қатысты көптеген шағымданулар бойынша өзін-өзі бағалауы (қанағаттанарлық немесе нашар) арасында айырмашылық болмады.

Бірінші буын иммигранттардың басым бөлігі жергілікті жасөспірімдер мен екінші буынды иммигрант-құрдастарымен салыстырғанда психика саулығы бойынша қиыншылыққа душар боп келеді.

Шылым шегу жиілігі, электрондық темекі және алкоголь тұтыну, сондай-ақ булинг және кибербуллинг бірінші ұрпақ иммигранттары арасында жергілікті жасөспірімдерге және екінші буынды иммигранттарға қарағанда әлдеқайда жоғары болып тұр.

қорытынды. Қазақстандық контекстте иммиграция жасөспірімдердің психикалық тұрақтылығы мен қауіпті мінез-құлқы үшін қауіп төндіреді, бұл әсіресе бірінші буынды көшіп-қонушылар арасында байқалады.

Негізгі сөздер: иммиграция, жасөспірімдер, оң денсаулық, психика тұрақтылығы, психика саулығы, қауіпті мінез-құлық.

\section{P E 3 Ю M E}

\section{ПСИХИЧЕСКОЕ БЛАГОПОЛУЧИЕ, ПОЗИТИВНОЕ ЗДОРОВЬЕ И РИСКОВАННОЕ ПОВЕДЕНИЕ СРЕДИ ПОДРОСТКОВ-ИММИГРАНТОВ В КАЗАХСТАНЕ}

Шынар 3. АБДРАХМАНОВА', https://orcid.org/0000-0003-3504-0427,

Асель А. АДАЕВА', https://orcid.org/0000-0001-9013-5248,

Татьяна И. СЛАЖНЕВА ${ }^{2}$, https://orcid.org/0000-0003-3632-486X,

Ботагоз С. ТУЛТАЕВА', https://orcid.org/0000-0002-8424-9641

${ }^{1}$ Национальный Центр общественного здравоохранения, 2. Нур-Султан, Республика Казахстан,

${ }^{2}$ Казахстанский медицинский университет «Высшая школа общественного здравоохранения», г. Алматы, Республика Казахстан

Каждая страна может стать страной происхождения, транзита или назначения беженцев и ми-
грантов. Зачастую решение об иммиграции принимают взрослые члены семьи, не учитывая мнение
детей. Как результат, иммиграция может выступать в качестве травмирующего фактора для них, так
как предполагает отрыв от привычной социокультурной среды (двор, город, школа и т.д.) и устояв-
шегося круга общения (одноклассники, знакомые, друзья). В связи с этим здоровье детей-мигрантов шегося круга общения (одноклассники, зна
является частью общественного здоровья.

Цель исследования. В этом исследовании изучалось влияние миграционного статуса на показатели позитивного здоровья, а также благополучия и рискованного поведения среди подростков в Республике Казахстан.

Материал и методы. Анализ основан на опросе «Поведение детей школьного возраста в отношении здоровья» (Health behavior in school-aged children, HBSC), впервые проведенном в Казахстане в 2017-2018 учебном году. Целевая группа - подростки 11, 13 и 15 лет: (n = 3992) (49,5\% девочек), среди них 191 подросток-мигрант первого поколения (4,8\%), 329 мигрантов второго поколения (8,2\%) и 3472 уроженца страны, подростки не иммигранты (87,0\%).

Результаты и обсуждение. Подростки-иммигранты и подростки не иммигранты не различались по распространенности удовлетворительной / плохой самооценки здоровья, высокой удовлетворенности жизнью, многочисленным жалобам на здоровье. Большая доля иммигрантов первого поколения, по сравнению с не иммигрантами и сверстниками-иммигрантами второго поколения, испытывали проблемы с психическим здоровьем. Частота курения сигарет, употребления электронных сигарет и алкоголя, а также буллинга и кибербуллинга были значительно выше среди иммигрантов первого поколения, чем среди коренных подростков-жителей страны и подростков-иммигрантов второго поколения.

Вывод. В казахстанском контексте иммиграция оказывает негативное влияние на психическое благополучие подростков и развитие рискованного поведения, что особенно выражено среди иммигрантов первого поколения.

Ключевые слова: иммиграция, подростки, позитивное здоровье, психическое благополучие, психическое здоровье, рискованное поведение.

Для цитирования: Абдрахманова Ш.З., Адаева А.А., Слажнева Т.И., Тултаева Б.С. Психическое благополучие, позитивное здоровье и рискованное поведение среди подростков-иммигрантов в Казахстане // Медицина (Алматы). - 2019. - №7-8 (205-206). - С. 2-9

$\mathbf{T}$ he health of children and adolescents is an important task for every society. Despite the great progress in terms of improving the health and development of children and adolescents, there are a number of issues that require study and attention, in particular, the health of migrant children and adolescents [1]. Over the few decades the rates of international migration has continued to grow rapidly. Worldwide 258 million people live in a country other than their country of birth, since 2000 the number of international migrants has increased by $49 \%$ [2]. Kazakhstan also faces migratory movements due to economic development and regional integration. Since the second half of 2000 the immigration to Kazakhstan has been increased, primarily from Central Asian countries, including ethnic Kazakhs migration. Kazakhstan becomes a country of 
destination and transit. Ethnic based immigration or repatriation of ethnic Kazakhs, so called "oralmans" to their homeland is a main priority of migration policy of Kazakhstan [3, 4, 5].

Since 1991, the country's independence, the Republic of Kazakhstan has become host country for 260325 families or 955894 ethnic Kazakhs (the data for 1 October 2015). They came from Uzbekistan (61.6\%), China (14.2\%), Mongolia (9.2\%), Turkmenistan 6.8\%,the Russian Federation (4.6\%) and $3.7 \%$ from other far-abroad countries. The ethnic migration continues, for example, for the 3rd quarter of 20172226 families or 4297 ethnic Kazakhs had received the "oralman" status [6]. In addition to ethnic Kazakh immigration, other ethnic groups migration as well as labour and illegal migration are growing. Kazakhstan is a home for a small percentage of refugees. According to the statistics, 640 people had refugee status in 2015 [6]. In general, migrants face economic, linguistic, social, cultural, psychological challenges in host country and considers as one of the most vulnerable groups of society. As a result, children and adolescent migrants are at higher risk for disadaptation in a different socioeconomic and cultural conditions [3, 7, 8]. Most of research highlights such aspects of integration as language proficiency, social and economic situations, school functioning, acculturation among migrant children [9, 10]. Various studies have assessed the effects of migration to health and well being with focus on mental health issues, psychological well-being, and involvement in risk behaviors of child migrants compared to the same indicators of native children $[11,12,13]$.

Studies on health and behaviors of migrant and non-immigrant children have contrasting outcomes. From one side having immigrant background could lead to lower social-economic status, problems with integration to a new society, discrimination or negative attitude towards them and other disadvantages. These stressful situations increase risks for mental and behavioral problems and refer adolescent immigrants as vulnerable group $[14,15,16]$.

From the other side, immigrant children's health and behavioral outcomes could be the same or even better than among nonimmigrant peers despite disadvantages. This phenomenon is called "immigrant paradox" [17].

Children from migrant families are commonly defined as first and second generation immigrants. First generation immigrants means that the child was not born in the country of residence. Second generation immigrants means the child was born in the country of residence, but one or two of the parents were not born in that country.

Much less is known on health of immigrant children and adolescents in Kazakhstan. Current research is limited in ethnic migrants', or oralmans' integration in a society focusing on sociodemografic characteristics, employment, housing, health care access and education issues as well as cultural integration, social and legal protection [3, 5]. One of the most serious problems in addressing the health of migrant children in the country is a limited reliable data on this topic. The data on children's health status and health services is not collected by migration status or ethnic origin, nationality, citizenship of parents.

A series of integration measures are provided by the state to ethnic repatriates namely, housing and reintegration allowances, other subsidies, free school education and health care, assistance in entering schools, preschools and social protec- tion institutions, assistance in learning Kazakh and Russian, grants for post-secondary education and etc. According to the data available the ethnic migrants experience challenges, so called "unequal start" which includes various aspects such as differences in education systems, financial problems, unemployment, housing, legal status of oralmans who came out of quota and others. The data on migrants, especially adolescents' health is scarce $[3,4,5]$.

Therefore, the objective of present paper is to examine positive health and well-being outcomes and risk behaviors among migrant adolescents compared to their native peers.

\section{MATERIAL AND METHODS}

Participants and procedures

The data is based on Health behavior in School-Aged Children survey (HBSC) first ever conducted in Kazakhstan in 2017-2018 academic year. HBSC is a cross-national survey conducted every four years in more than 40 countries and regions in Europe and North America (HBSC international protocol 2017-2018). The Republic of Kazakhstan since 2016 is an associate member of the HBSC research network. The HBSC survey collects data an adolescents health, health behavior, social determinants and well-being of 11,13 and 15 year old schoolchildren using standardized international protocol. Two stage cluster sampling was conducted with stratification by urbanization. The primary sampling unit was the school selected from the national list of all eligible school of the republic by standardized sampling method. From selected school one class was randomly drawn for each of three grades (5th, 7th and 9th) according to target age groups. The research tool is an anonymous questionnaire filled in by the school students themselves (self-reported) in the classroom. Parental passive inform consents were obtained and children were informed that they can choose whether or not to participate in the survey.

Immigration status was assessed through the following questions: "In which country were you born?, "In which country was your mother born?", "In which country was your father born?". Answer options included the resident country, a list of countries from which the five largest immigrant groups live in the country, and another country option to fill out.

The national sample included 6548 schoolchildren $(51.1 \%$ girls). 11,13 and 15 year old adolescents who had answered to the birth country questions were included into analysis $(n=3992)$ (49.5\% girls): 191 first generation migrant adolescents $(4.8 \%), 329$ second-generation migrants $(8.2 \%)$ and 3472 native-born, non-immigrant adolescents $(87,0 \%)$. Of the first generation migrant adolescents $57.1 \%(n=109)$ were born in Uzbekistan, $14.7 \%(\mathrm{n}=28)$ were born in Russia, $11.0 \%$ $(\mathrm{n}=21)$ were born in China, 6.8\% $(\mathrm{n}=13)$ were born in Kyrgyzstan, $4.2 \%(n=8)$ were born in Turkmenistan, $6.3(n=12)$ were born in other countries.

At least one of the parents of the second generation migrant adolescents were born in Uzbekistan $(27.4 \%$ mothers and $22.2 \%$ fathers) or: in Russian Federation $(21.3 \%$ mothers and $9.1 \%$ fathers), China (4.0\% mothers and $13.4 \%$ fathers), Turkmenistan (5.5\% mothers and 6.7\% fathers), Kyrgyzstan (4.3\% mothers and $2.1 \%$ fathers), other countries (10.3\% mothers and $9.7 \%$ fathers), in Kazakhstan (27.4\% mothers and 34.7\% fathers). 


\section{Measures}

Positive health and well-being. These measures assess adolescents subjective health and well-being and include self-rated health, life-satisfaction, health complaints and WHO 5 Well-being Index. Good state of physical and mental health are important for adolescents to deal with issues during transition to adulthood. Self-rated health is a subjective evaluation of health and well-being. Children were asked a question:"Would you say your health is.....?" with the four response categories, such as "excellent", "good", "fair" and "poor". The response categories were analyzed as "excellent, good health" vs "fair and poor health".

The Cantril ladder was used for measurement of life satisfaction with 11 scores ranging from "10" - "Best possible life" at the top of the ladder to "0" - "Worst possible life". The schoolchildren were asked to indicate "Where on the ladder do you feel you stand at the moment?" The high level of satisfaction were defined as score of six or more.

Health complaints measured the following subjective psychosomatic symptoms: headache, abdominal pain, backache, feeling low, irritability or bad mood, feeling nervous, sleeping difficulties and dizziness. The respondents were asked how often they had experienced these symptoms in the last six months. Answer options were the following: about every day, more than once a week, about every week, about every month, rarely or never. For the purpose of this paper, the multiple health complaints (two or more complaints more than once a week during the past 6 month) scoring was calculated among migrant and non-migrant adolescents.

The WHO-5 Well-being Index is a short, self-administered questionnaire covering 5 positively worded items, related to positive mood (good spirits, relaxation), vitality (being active and waking up fresh and rested), and general interests (being interested in things). It has shown to be a reliable measure of emotional functioning and a good screener for depression.

Mental well-being assessed by the five item World Health Organization Well-Being Index (WHO-5). The index is considered as good screening tool for depression with sufficiently high sensitivity. WHO-5 consists of 5 simple statements: "I have felt cheerful and in good spirits", I have felt calm and relaxed, I have felt active and vigorous, I woke up feeling fresh and rested My daily life has been filled with things that interest me/ The respondents were asked to indicate for each of the five statements which is closest to how you have been feeling during the last two weeks. The responses ranged from "At no time" to "All of the time".

Each of the five statements was rated on a 6-point Likert scale from 0 (= not present) to 5 (= constantly present). Scores were summated and the raw score had ranged from 0 to 25 . The scores were transformed to $0-100$ by multiplying by 4 . A score of 50 or below was considered as low well-being, but not necessarily depression. A score of 28 or below indicates likely depression and warrants further diagnostics to confirm clinical depression $[18,19]$.

Risk behaviors

Lifetime prevalence and last 30 days prevalence smoking cigarettes were measured by asking on how many days (if any) had they smoked cigarettes. Responses varied from never, 1-2 days, 3-5 days, 6-9 days, 10-19 days, 20-29 days, 30 days or more.
Current smoking was assessed by asking respondents how often do they smoke tobacco at present to measure daily or weekly smoking. The answer options were "every day", "at least once a week, but not every day", "less than once a week', I do not smoke".

Lifetime and last 30 days electronic cigarettes use was also examined. Frequency of the lifetime and last 30 days alcohol consumption were measured by the following question: "On how many days (if any) have you drunk alcohol?" with the same response options as for cigarettes smoking and e-cigarettes use.

Involvement in physical fighting was measured by asking how many times in the past 12 months had adolescents been involved in a physical fight. The answers were ranged from none to four times or more.

Bullying and cyberbullying were also examined as forms of youth violence by separate questions. The respondents were asked how often they had been bullied (at school)/or cyberbullied in the past couple of months. The bullying or cyberbullying victimizations (being bullied or cyberbullied) was examined by asking the young people how often they had been bullied at school or cyberbullied in the past couple of months. Each question on bullying and cyberbullying was preceded by the definitions of bullying and cyberbullying respectively. Response categories included options "I have not bullied (cyberbullied) another person (s)", alternatively, "I have not been bullied/cyberbullied"; "it has happened once or twice"; "2 or 3 times a month"; "about once a week"; "several times a week".

For the purpose of this paper the proportions who indicated being bullied or cyberbullied and bullying or cyberbullying others at least two or three times a month were analyzed.

\section{Statistical analysis}

Statistical processing was conducted using Excel and SPSS 15.0 for Windows. When analyzing the contingency tables, the Pearson Pearson's chi-square test was used. The value of $p$ $<0.05$ is considered as the presence of statistically significant difference.

\section{RESULTS}

Table 1 provides the data on positive health and well-being outcomes and risk behavior form first, second generation immigrants and non-immigrant adolescents.

No significant immigrant status difference was found in relation to self-rated health, life satisfaction and multiple health complaints among adolescents. $7.9 \%$ of first generation and $11.3 \%$ second generation immigrants rated their health as fair or poor compared to $8.3 \%$ of native adolescents.

The majority of the migrant adolescents $(88.5 \%$ and $88.6 \%)$ regardless generation categories had normal and high level of life satisfaction. About one fifth of the migrant participants had multiple health complaints more than once a week.

Mental well-being data showed significant difference between first generation immigrants and their non-immigrant peers as well as between second generation migrants. Higher proportion of first-immigrant adolescents reported low and very poor well-being (likely depression) compared to non-immigrant ones and second generation immigrants $(p<0.01)$.

Every day and weekly current cigarette smoking rates were higher among first immigrants compared to non-immigrants 
$(p<0.001)$. Lifetime cigarette smoking experience of 1-9 days was higher among the second generation migrants, and 30 days and more was higher among the first generation migrants compared to native respondents $(\mathrm{p}<0.001)$.

Recent, (in the past 30 days) cigarette smoking was higher among first generation immigrants than among non-immigrants $(\mathrm{p}<0.001)$.
Lifetime and past 30 days use of e-cigarettes also was more prevalent among first generation immigrants compared to non-immigrant adolescents.

Higher proportion of immigrant adolescents had used alcohol in their lifetime and post 30 days than non-immigrants. Second generation migrant children tended to smoke cigarettes, use e-cigarettes and use alcohol less number of days

Table 1

\begin{tabular}{|c|c|c|c|c|}
\hline & $\begin{array}{l}\text { First generation } \\
\text { immigrants }\end{array}$ & $\begin{array}{l}\text { Second- } \\
\text { generation } \\
\text { immigrants }\end{array}$ & Non-immigrants & $\mathrm{p}$ value \\
\hline Self-rated health: fair+poor & $7.9 \%$ & $11.3 \%$ & $8.3 \%$ & \\
\hline $\begin{array}{l}\text { Life-satisfaction: high level } \\
\text { (6-10 scores) }\end{array}$ & $88.5 \%$ & $88.6 \%$ & $91.5 \%$ & \\
\hline $\begin{array}{l}\text { Multiple health complaints: two or } \\
\text { more health complaints more than } \\
\text { once a week }\end{array}$ & $28.2 \%$ & $24.8 \%$ & $24.9 \%$ & \\
\hline $\begin{array}{l}\text { The WHO-5 Well-being Index: } \\
\text {-low well-being (29-50) } \\
\text {-very low well-being, likely } \\
\text { depression }(0-28)\end{array}$ & $\begin{array}{l}16.4 \% \\
11.1 \%\end{array}$ & $\begin{array}{l}18.2 \% \\
3.7 \%\end{array}$ & $\begin{array}{l}18.5 \% \\
4.9 \%\end{array}$ & $\mathrm{p}<0.01$ \\
\hline $\begin{array}{l}\text { Current smoking: every day } \\
\text { weekly }\end{array}$ & $\begin{array}{l}5.1 \% \\
2.3 \%\end{array}$ & $\begin{array}{l}3.5 \% \\
0.3 \%\end{array}$ & $\begin{array}{l}2.0 \% \\
0.5 \%\end{array}$ & $\mathrm{p}<0.001$ \\
\hline $\begin{array}{l}\text { Lifetime smoking: } \\
1-9 \text { days } \\
10-29 \text { days } \\
30+\text { days }\end{array}$ & $\begin{array}{l}3.8 \% \\
1.1 \% \\
4.4 \% \\
\end{array}$ & $\begin{array}{l}5.9 \% \\
0.3 \% \\
1.5 \% \\
\end{array}$ & $\begin{array}{l}2.9 \% \\
0.6 \% \\
0.8 \%\end{array}$ & $\mathrm{p}<0.001$ \\
\hline $\begin{array}{l}30 \text { days smoking: } \\
1-9 \text { days } \\
10-29 \text { days } \\
30+\text { days }\end{array}$ & $\begin{array}{l}0.6 \% \\
2.4 \% \\
3.6 \% \\
\end{array}$ & $\begin{array}{l}3.3 \% \\
1.0 \% \\
1.3 \% \\
\end{array}$ & $\begin{array}{l}2.2 \% \\
0.8 \% \\
0.1 \% \\
\end{array}$ & $\mathrm{p}<0.001$ \\
\hline $\begin{array}{l}\text { Lifetime e-cigarette use: } \\
1-9 \text { days } \\
10-29 \text { days } \\
30+\text { days }\end{array}$ & $\begin{array}{l}3.3 \% \\
2.2 \% \\
3.3 \%\end{array}$ & $\begin{array}{l}7.2 \% \\
1.6 \% \\
0.6 \%\end{array}$ & $\begin{array}{l}4.7 \% \\
0.5 \% \\
0.5 \%\end{array}$ & $\mathrm{p}<0.001$ \\
\hline $\begin{array}{l}30 \text { days e-cigarette use: } \\
1-9 \text { days } \\
10-29 \text { days } \\
30+\text { days }\end{array}$ & $\begin{array}{l}2.3 \% \\
1.2 \% \\
2.9 \%\end{array}$ & $\begin{array}{l}3.3 \% \\
0.3 \% \\
0.7 \%\end{array}$ & $\begin{array}{l}2.1 \% \\
0.3 \% \\
0.3 \%\end{array}$ & $\mathrm{p}<0.001$ \\
\hline $\begin{array}{l}\text { Lifetime alcohol use: } \\
1-9 \text { days } \\
10-29 \text { days } \\
30+\text { days }\end{array}$ & $\begin{array}{l}4.4 \% \\
1.1 \% \\
2.2 \% \\
\end{array}$ & $\begin{array}{l}5.9 \% \\
1.2 \% \\
0.6 \% \\
\end{array}$ & $\begin{array}{l}3.4 \% \\
0.4 \% \\
0.4 \% \\
\end{array}$ & $\mathrm{p}<0.001$ \\
\hline $\begin{array}{l}30 \text { days alcohol use: } \\
1-9 \text { days } \\
10-29 \text { days } \\
30+\text { days }\end{array}$ & $\begin{array}{l}1.2 \% \\
1.8 \% \\
2.4 \% \\
\end{array}$ & $\begin{array}{l}3.9 \% \\
0.7 \% \\
0.0 \% \\
\end{array}$ & $\begin{array}{l}1.8 \% \\
0.3 \% \\
0.1 \% \\
\end{array}$ & $\mathrm{p}<0.001$ \\
\hline $\begin{array}{l}\text { Bullying others two or three times } \\
\text { a month }\end{array}$ & $12.7 \%$ & $6.0 \%$ & $8.3 \%$ & \\
\hline $\begin{array}{l}\text { Being bullied two or three times a } \\
\text { month }\end{array}$ & $14.8 \%$ & $6.0 \%$ & $6.3 \%$ & $\mathrm{p}<0.001$ \\
\hline $\begin{array}{l}\text { Cyber bullying others two or three } \\
\text { times a month }\end{array}$ & $10.9 \%$ & $5.4 \%$ & $4.9 \%$ & $p<0.001$ \\
\hline $\begin{array}{l}\text { Being cyber bullied two or three } \\
\text { times a month }\end{array}$ & $9.2 \%$ & $5.4 \%$ & $4.5 \%$ & $\mathrm{p}<0.005$ \\
\hline $\begin{array}{l}\text { Involvement in physical fights three } \\
\text { or more times }\end{array}$ & $12.2 \%$ & $8.4 \%$ & $7.1 \%$ & \\
\hline
\end{tabular}


in their lifetime and last 30 days compared to first generation migrants.

No differences were revealed between immigrants and non-immigrants on involvement in bullying others at school. However bullying victimization (being bullied) did show differences between first generation immigrants and non-immigrants, and between two immigrant categories. The first generation immigrants had the highest rate of being bullied at school among others $(\mathrm{p}<0.001)$.

Involvement in cyberbullying at least two or three times a month in the past couple of months was higher among first generation immigrants compared to the second generation immigrants and non-immigrants $(\mathrm{p}<0.001)$. Similarly, the proportions of adolescents who reported being cyberbullied at least two or three times a month were higher for first generation immigrants than for second generation immigrants and native adolescents $(\mathrm{p}<0.005)$.

No differences were found between immigrants and non-immigrants on involvement in physical fights.

\section{DISCUSSION}

Both generations of immigrant adolescents shows the same level of self-rated health, life-satisfaction and multiple health complaints as do their native counterparts. It may be explained by supportive migration policies in Kazakhstan and complex interplay of individual experiences, socio-economic, cultural backgrounds and integration to host-community. Earlier data from HBSC 2004-2005 survey based on 12 European countries showed no differences between foreign-born children and their non-immigrant peers on general self-health assessment and high level life-satisfaction with some exceptions. In Wales the proportion of foreign -born children experiencing excellent health was higher than of native peers and in Ireland immigrant children less likely had high life satisfaction compared to non-immigrants [7]. More recent international comparative study from 10 European countries and the United States based on HBSC 2010 showed low level of life satisfaction reported by both generation immigrants [14]. Also, data on 11, 13 and 15 year old Italian youth from HBSC revealed that migrant adolescents more often had health complaints, were less satisfied with their life and health [20].

The results show that higher proportion of first generation migrant adolescents in Kazakhstan have mental health problems compared with second generation immigrant and native peers. These findings are consistent with some previous research. Studies on adolescent migrants' health in Israel revealed higher level of mental symptoms among 1.5 and second generation immigrants than among non-immigrants [21]. Another study in Israel showed that immigrant adolescents from the former Soviet Union had lower mental health [22].

Turkish immigrant children on Netherland were more likely to have behavioral problems and depression [23]. On the other side, several studies reported similarities in mental health issue between immigrant children and native peers in Canada [24], Australia [25], the US [26]. In non Western setting (Hong Kong) migration was not associated with depressive symptoms among 7 and 11 year olds [27].

Our study has found that unlike their native peers and the second generation immigrants, the first generation immigrants had higher involvement of into current smoking, lifetime and 30 days cigarette smoking, e-cigarettes and alcohol use, bulluing victimization and cyberbulying others and being cyberbulled.

Data from countries on migrant risk behavior show various results. In Israel, immigrant adolescents from former Soviet Union and Ethiopia had higher levels of cigarettes smoking, binge drinking and being drunk $[22,28]$. Intercountry analysis of data from 12 European countries found that foreign born children from Germany, Greece, Italy, Spain and Sweden had higher likelihood of involvement in a physical fight, while immigrant children in Ireland, Scotland and Spain were more likely to a bullying victims, and foreign born children in Greece were more likely to have a history of drunkenness [6].

Higher levels of risk behaviors among 1.5 and second generation immigrants were revealed in the study in Israel compared with native peers without significant differences among generations of immigrant adolescents [21].

Recent intercountry comparison of alcohol consumption among first- and second-generation immigrant and native adolescents in 23 countries demonstrated higher alcohol use among natives compared to first and second generation immigrants and no differences between two immigrant categories [13].

The study has several limitations. The survey had conducted using self-reported data. The gender, age were not analyzed as well as the effects of socio-economic factors on studied variables and relationship between ethnic background and health outcomes and risk behaviors. The data presented is first ever data on health and well-being and risky behaviors of migrant adolescent population in Kazakhstan and could be considered as an evidence of the impacts of immigration status to health outcomes and behaviors in this part of the world.

\section{CONCLUSION}

Both generation migrant adolescents show high self-rated health and life-satisfaction, no differences in multiple health complaints. However, migrant adolescents in the country are at higher risk for mental health problems and involvement to cigarette smoking, e-cigarette and alcohol use, as well as bullying and cyber bullying. Signs of depressions, current cigarette smoking, high frequency of lifetime and 30 days smoking, e-cigarette and alcohol use, bullying and cyber bullying victimization, and cyber bullying others were higher among first generation migrants. These findings point to first generation migrant adolescents as the most vulnerable group in migration process. A complex policy, health care and education sectors involvement and further focused studies are required to address migrant children integration, health and well-being.

\section{Research transparency}

Research did not have a sponsorship. The authors are absolutely responsible for presenting the release script for publication.

\section{Declaration about financial and other relations}

All authors took part in elaboration of article conception and writing the script. The release script was approved by all authors. The authors did not get the honorary for the article.

\section{Conflict of interest}

The authors declare no conflict of interest.

\section{Ethical statement}

Parental passive inform consents were obtained and children were informed that they can choose whether or not to participate in the survey. 


\section{СПИСОК ЛИТЕРАТУРЫ}

1 Баттакова Ж.Е., Мукашева С.Б., Абдрахманова Ш.З. Европейская стратегия по охране здоровья детей и подростков - основа для действий по усилению мер здравоохранения и других секторов // Медицина (Алматы). - 2017. - №8 (182). - С. 2-5

2 The International Migration Report 2017 (Highlights) United Nations New York, 2017

3 Chandonnet A., Tursunaliev U., Jamangulov K., Chernykh I., Amandurdyyeva G. Migrants' Right to Health in Central Asia: Challenges and Opportunities. - Almaty: Triada Print, 2017

4 Status of oralmans in Kazakhstan. An overview. - Almaty, 2006. - P. 33

5 Sultanov K., Abishev T. Commission on Human Rights under the President of the Republic of Kazakhstan. Special report "On the situation with the rights of oralmans, stateless persons and refugees in the Republic of Kazakhstan". - 2012

6 Information on ethnic migration on October 1, 2015. Bulletin. Statistics from the Ministry of labour and social protection. http:// www.enbek.gov.kz/ru/node/332244.

7 Foreing-born children in Europe: an Overview from the Healgth Behaviour in School-aged Children (HBSC) Study. International Organization for Migration. Background paper. - 2006

8 Pantin H., Schwartz S.J., Sullivan S., Coatsworth J.D., Szapocznik J. Preventing Substance Abuse in Hispanic Immigrant Adolescents: An Ecodevelopmental, Parent-Centered Approach // Hispanic Journal of Behavioral Sciences. - 2003. - Vol. 25(4). P. 469-500. DOI: $10.1177 / 0739986303259355$

9 Pawliuk N., Grizenko N., Chan-Yip A., Gantous P., Mathew J., Nguyen D. Acculturation style and psychological functioning in children of immigrants // Am J Orthopsychiatry. - 1996. - Vol. 66(1). - P. 111-121

10 Strohmeier D., Schmitt-Rodermund E. Immigrant youth in European countries: The manifold challenges of adaptation // European Journal of Developmental Psychology. - 2008. - Vol. 5 (2). P. $129-137$

11 Noam G., Oppedal B., Idsoe T., Panjwani N. Mental Health Problems and School Outcomes Among Immigrant and Non-immigrant Early Adolescents in Norway // School Mental Health. - Vol. 6, 4. - P. 279-293. DOI: 10.1007/s12310-014-9129-5

12 Stevens G.W., Vollebergh W.A. Mental health in migrant children // J Child Psychol Psychiatry. - 2008. - Vol. 49:276e94.

13 Barsties L.S., Walsh S.D., Huijts T., Bendtsen P., Molcho M., Buijs T. et al. Alcohol consumption among first- and second-generation immigrant and native adolescents in 23 countries: Testing the importance of origin and receiving country alcohol prevalence rates // Drug and Alcohol Review. - 2017. - Vol. 36 (6). - P. 769-778

14 Stevens G., Walsh S.D., Huijts T., Maes M., Madsen K.R., Cavallo F. et al. An Internationally Comparative Study of Immigration and Adolescent Emotional and Behavioral Problems: Effects of Generation and Gender // Journal of Adolescent Health. - 2015. Vol. 57 (6). - P. 587-594

15 Guarnaccia P.J., Lopez S. The mental health and adjustment of immigrant and refugee children // Child and Adolescent Psychiatric Clinics of North America. - 1997. - Vol. 7. - P. 537-553

16 Pascoe E.A., Richman L.S. Perceived discrimination and health: A meta-analytic review // Psychological Bulletin. - 2009. Vol. 135. - P. 531-554

17 Garcia Coll C., Marks A.K. The immigrant paradox in children and adolescents: Is becoming American a developmental risk? - Washington DC: American Psychological Association, 2011

18 Topp C.W., Østergaard S.D., Søndergaard S.A., Bech P. The WHO-5 Well-Being Index: A Systematic Review of the Literature // Psychother Psychosom. - 2015. - Vol. 84. - P. 167-176. https://doi. org/10.1159/000376585

19 Brian A Primack. The WHO-5 Wellbeing index performed the best in screening for depression in primary care // BMJ Evidence-Based Medicine. - 2003. - Vol. 8. - P. 155. http://dx.doi. org/10.1136/ebm.8.5.155

\section{REFERENCES}

1 Battakova ZhE, Mukasheva SB, Abdrakhmanova ShZ. The European strategy for protecting the health of children and adolescents - the basis for action to strengthen health measures and other sectors. Meditsina (Almaty) = Medicine (Almaty). 2017;8(182):2-5 (In Russ.)

2 The International Migration Report 2017 (Highlights) United Nations New York; 2017

3 Chandonnet A, Tursunaliev U, Jamangulov K, Chernykh I, Amandurdyyeva G. Migrants' Right to Health in Central Asia: Challenges and Opportunities. Almaty: Triada Print; 2017

4 Status of oralmans in Kazakhstan. An overview. Almaty; 2006. P. 33

5 Sultanov K, Abishev T. Commission on Human Rights under the President of the Republic of Kazakhstan. Special report "On the situation with the rights of oralmans, stateless persons and refugees in the Republic of Kazakhstan". 2012

6 Information on ethnic migration on October 1, 2015. Bulletin. Statistics from the Ministry of labour and social protection. Available from: http://www.enbek.gov.kz/ru/node/332244.

7 Foreing-born children in Europe: an Overview from the Healgth Behaviour in School-aged Children (HBSC) Study. International Organization for Migration. Background paper. 2006

8 Pantin H, Schwartz SJ, Sullivan S, Coatsworth JD, Szapocznik J. Preventing Substance Abuse in Hispanic Immigrant Adolescents: An Ecodevelopmental, Parent-Centered Approach. Hispanic Journal of Behavioral Sciences. 2003;25(4):469-500. DOI: $10.1177 / 0739986303259355$

9 Pawliuk N, Grizenko N, Chan-Yip A, Gantous P, Mathew J, Nguyen D. Acculturation style and psychological functioning in children of immigrants. Am J Orthopsychiatry. 1996;66(1):111-21

10 Strohmeier D, Schmitt-Rodermund E. Immigrant youth in European countries: The manifold challenges of adaptation. European Journal of Developmental Psychology. 2008;5(2):129-37

11 Noam G, Oppedal B, Idsoe T, Panjwani N. Mental Health Problems and School Outcomes Among Immigrant and Non-immigrant Early Adolescents in Norway. School Mental Health. 6,4:2793. DOI: $10.1007 / \mathrm{s} 12310-014-9129-5$

12 Stevens GW, Vollebergh WA. Mental health in migrant children. J Child Psychol Psychiatry. 2008;49:276e94.

13 Barsties LS, Walsh SD, Huijts T, Bendtsen P, Molcho M, Buijs $\mathrm{T}$, et al. Alcohol consumption among first- and second-generation immigrant and native adolescents in 23 countries: Testing the importance of origin and receiving country alcohol prevalence rates. Drug and Alcohol Review. 2017;36(6):769-78

14 Stevens G, Walsh SD, Huijts T, Maes M, Madsen KR, Cavallo F, et al. An Internationally Comparative Study of Immigration and Adolescent Emotional and Behavioral Problems: Effects of Generation and Gender. Journal of Adolescent Health. 2015;57(6):587-94

15 Guarnaccia PJ, Lopez S. The mental health and adjustment of immigrant and refugee children. Child and Adolescent Psychiatric Clinics of North America. 1997;7:537-53

16 Pascoe EA, Richman LS. Perceived discrimination and health: A meta-analytic review. Psychological Bulletin. 2009;135:531-54

17 Garcia Coll C, Marks AK. The immigrant paradox in children and adolescents: Is becoming American a developmental risk? Washington DC: American Psychological Association; 2011

18 Topp CW, Østergaard SD, Søndergaard SA, Bech P. The WHO5 Well-Being Index: A Systematic Review of the Literature. Psychother Psychosom. 2015;84:167-76. https://doi.org/10.1159/000376585

19 Brian A Primack. The WHO-5 Wellbeing index performed the best in screening for depression in primary care. BMJ Evidence-Based Medicine. 2003;8:155. http://dx.doi.org/10.1136/ebm.8.5.155

20 Vieno A, Santinello M, Lenzi M, Baldassari D, Mirandola M. Health Status in Immigrants and Native Early Adolescents in Italy. Journal Of Community Health. 34(3):181-7

21 Shoshani A, Nakash O, Zubida H, Harper RA. School Engagement, Acculturation, and Mental Health Among Migrant Adolescents in Israel. School Psychology Quarterly. 2016;31(2):181-97 
20 Vieno A., Santinello M., Lenzi M., Baldassari D., Mirandola M. Health Status in Immigrants and Native Early Adolescents in Italy // Journal Of Community Health. - Vol. 34 (3). - P. 181-187

21 Shoshani A., Nakash O., Zubida H., Harper R.A. School Engagement, Acculturation, and Mental Health Among Migrant Adolescents in Israel // School Psychology Quarterly. - 2016. - Vol. 31 (2). - P. 181-197

22 Walsh S.D., Harel-Fisch Y., Fogel-Grinvald H. Parents, teachers and peer relations as predictors of risk behaviors and mental well-being among immigrant and Israeli born adolescents // Social Science \& Medicine. - 2010. - Vol. 70 (7). - P. 976-984

23 Bengi-Arslan L., Verhulst F.C., van der Ende J. et al. Understanding childhood (problem) behaviors from a cultural perspective: comparison of problem behaviors and competencies in Turkish immigrant, Turkish and Dutch children // Soc Psychiatry Psychiatr Epidemiol. - 1997. - Vol. 32. - P. 477. https://doi.org/10.1007/ BF00789143

24 Ma Xin. The First Ten Years in Canada: A Multi-Level Assessment of Behavioural and Emotional Problems of Immigrant Children Canadian Public Policy // Analyse de Politiques. - 2002. - Vol. 28, No. 3. - P. 395-418

25 Davies L.C., McKelvey R.S. Emotional and behavioural problems and competencies among immigrant and non-immigrant adolescents // Aust N Z J Psychiatry. - 1998. - Vol. 32(5). - P. 658-665

26 Blake S.M., Ledsky R., Goodenow C., O'Donnell L. Recency of immigration, substance use, and sexual behavior among Massachusetts adolescents // Am J Public Health. - 2001. - Vol. 91 (5). P. 794-798

27 Leung C.Y., Leung G.M., Schooling C.M. Migrant status and child and adolescent psychological well-being: evidence from Hong Kong's 'Children of 1997' birth cohort // Journal of Epidemiology and Community Health. - 2015. - Vol. 69 (2). - P. 156-161

28 Walsh S.D., Djalovski A., Boniel-Nissim M., Harel-Fisch Y. Parental, peer and school experiences as predictors of alcohol drinking among first and second generation immigrant adolescents in Israel // Drug and Alcohol Dependence. - 2014. - Vol. 138. - P. 39-47
22 Walsh SD, Harel-Fisch Y, Fogel-Grinvald H. Parents, teachers and peer relations as predictors of risk behaviors and mental well-being among immigrant and Israeli born adolescents. Social Science \& Medicine. 2010;70(7):976-84

23 Bengi-Arslan L, Verhulst FC, van der Ende J, et al. Understanding childhood (problem) behaviors from a cultural perspective: comparison of problem behaviors and competencies in Turkish immigrant, Turkish and Dutch children. Soc Psychiatry Psychiatr Epidemiol. 1997;32:477. https://doi.org/10.1007/BF00789143

24 Ma Xin. The First Ten Years in Canada: A Multi-Level Assessment of Behavioural and Emotional Problems of Immigrant Children Canadian Public Policy. Analyse de Politiques. 2002;28(3):395-418

25 Davies LC, McKelvey RS. Emotional and behavioural problems and competencies among immigrant and non-immigrant adolescents. Aust N Z J Psychiatry. 1998;32(5):658-65

26 Blake SM, Ledsky R, Goodenow C, O'Donnell L. Recency of immigration, substance use, and sexual behavior among Massachusetts adolescents. Am J Public Health. 2001;91(5):794-8

27 Leung CY, Leung GM, Schooling CM. Migrant status and child and adolescent psychological well-being: evidence from Hong Kong's 'Children of 1997' birth cohort. Journal of Epidemiology and Community Health. 2015;69(2):156-61

28 Walsh SD, Djalovski A, Boniel-Nissim M, Harel-Fisch Y. Parental, peer and school experiences as predictors of alcohol drinking among first and second generation immigrant adolescents in Israel. Drug and Alcohol Dependence. 2014;138:39-47 